\title{
Ultrasonic Sensors-Assisted Corrosion Studies on Surface Coated AlSi9Cu3 Alloy Die Castings
}

\author{
Yuh-Chung $\mathrm{Hu}^{1}{ }^{1}$, Senthil Kumaran Selvaraj ${ }^{2}{ }^{-0}$, Manivannan Subramanian ${ }^{3}{ }^{\circledR}$, \\ Kathiravan Srinivasan ${ }^{4, *(D)}$ and Srinivasan Narayanan ${ }^{5}$ (D) \\ 1 Department of Mechanical and Electromechanical Engineering, National ILan University, No. 1, Sec. 1, \\ Shenlung Rd., ILan City, ILan County 26041, Taiwan; ychu@niu.edu.tw \\ 2 Department of Manufacturing Engineering, School of Mechanical Engineering, Vellore Institute of \\ Technology (VIT), Vellore 632014, India; senthilkumaran.s@vit.ac.in \\ 3 Department of Mechanical Engineering, Karpagam Academy of Higher Education, Coimbatore 641021, \\ India; manivannan.s@kahedu.edu.in \\ 4 School of Information Technology and Engineering, Vellore Institute of Technology (VIT), \\ Vellore 632014, India \\ 5 School of Mechanical Engineering, Vellore Institute of Technology (VIT), Vellore 632014, India; \\ srinivasan.narayanan@vit.ac.in \\ * Correspondence: kathiravan.srinivasan@vit.ac.in
}

Received: 19 November 2019; Accepted: 16 January 2020; Published: 19 January 2020

\begin{abstract}
A novel phenomenon known as Industry X.0 is becoming extremely popular for digitizing and reinventing business organizations through the adaption of rapid and dynamic technological, innovational, and organizational changes for attaining the profitable revenue. This work investigates the die-casted commercially pure aluminum alloyed with $9 \%$ silicon and $3 \%$ copper $\left(\mathrm{AlSi}_{9} \mathrm{Cu}_{3}\right)$ that is produced through the gravity die casting process. Further, the degradation of surface coating on die-casted $\mathrm{AlSi}_{9} \mathrm{Cu}_{3}$ alloy was explored. The acrylic paint electrodeposition (ED) coat, 2-coat polyester without primer and 3-coat polyester with epoxy primer powder coatings were used in this study. Moreover, the $3.5 \mathrm{wt} . \%$ of sodium chloride ( $3.5 \mathrm{wt} . \%$ of $\mathrm{NaCl}$ ) test solution was used for electrochemical and salt spray test and the tools used to assess electrochemical properties were electrochemical impedance spectroscopy (EIS), potentiodynamic polarization, and neutral salt spray test (NSS). The microstructure of $\mathrm{AlSi}_{9} \mathrm{Cu}_{3}$ after corrosion exposure was investigated; also, the microstructure of coated and uncoated $\mathrm{AlSi}_{9} \mathrm{Cu}_{3}$ samples was analyzed by SEM microscopy after corrosion exposure. Besides, the electrochemical studies were also carried out on the $\mathrm{Al}$ alloy die casting. It was found that acrylic paint ED coatings exhibited higher corrosion resistance than 2-coat polyester without primer \& 3-coat polyester with epoxy primer powder coatings. Acrylic paint ED coating showed higher corrosion resistance in $\mathrm{AC}$ and a lower value in $\mathrm{DC}$ and 3-coat polyester with epoxy primer powder coating displayed higher corrosion resistance in DC and a lower value in AC.
\end{abstract}

Keywords: coating; EIS and salt spray test; potentiodynamic polarization; $\mathrm{NaCl}$ solution; ultrasonic sensors

\section{Introduction}

In recent years, Industry X.0 has dramatically influenced and impacted the digital-driven transformations in the manufacturing and production-based industrial corporations. Further, hard coatings are a widespread phenomenon that is utilized in several arduous applications, including the aerospace industry, other applications that involve machining tools, die-casting tools, molding tools, stamping tools. Johansen et al. have worked in corrosion protection of aluminum alloy by cerium conversion and coating polymer duplex coatings. In this research work, the corrosion protection 
of AA6063 aluminum alloy by cerium conversion, polyaniline conducting polymer, and by duplex coatings has been investigated in detail [1]. In general, the electrochemical behavior is evaluated in aerated $3.5 \mathrm{wt} . \% \mathrm{NaCl}$. In this research work, cerium conversion, and duplex coatings were studied. Baldissera et al. have reviewed the coatings for corrosion protection of metals based on electronic conducting polymers [2]. Additionally, the corrosion protection of mild steel by a novel epoxy resin-based coating system was investigated. The foremost goal of this study was to demonstrate that the addition of a conducting polymer to a coating based on a classic polymer results in improved corrosion protection of steel.

Zelinka et al. investigated the electrochemical impedance spectroscopy, which acts as a tool for measuring corrosion of polymer-coated fasteners [3]. In this study, the corrosion performance of polymer-coated metals was measured using EIS. The low-frequency corrosion-time constant was measured for all of the fasteners. Frankel et al. studied the electrochemical techniques in corrosion and its status, limitations, and needs [4]. Primarily the corrosion of metals occurs by an electrochemical process that involves metal oxidation and reduction of some other species. Moreover, understanding the fundamentals of this process has allowed the development of many electrochemical techniques for the assessment of the corrosion rate and the study of the corrosion phenomena. Further, this paper describes the status of electrochemical techniques, their limitations, and where non-electrochemical methods are required.

Kumar et al. have investigated on corrosion-resistant epoxy interpenetrating coatings of siliconized over mild steel surface by the electrochemical method [5]. Electrochemical techniques comprising of electrochemical impedance spectroscopy (EIS), Potentiodynamic polarization, and salt-spray test (SST) were used for assessing corrosion-resistant of the coating. From the result obtained from electrochemical potential measurement for epoxy and siliconized epoxy coating systems, it was found to be the best corrosion-resistant coating systems. Mansfeld et al. worked the evaluation of corrosion protection by polymer coatings using electrochemical impedance spectroscopy and noise analysis [6]. In the steel, the degradation of different polymer coating systems exposed to neutral and artificial seawater had been monitored using electrochemical impedance spectroscopy and noise analysis.

The aerospace industry extensively uses aluminum alloys such as $\mathrm{AlCuMg}, \mathrm{AlSiCu}$, and $\mathrm{AlZnMg}$ series due to excellent mechanical properties [7]. Aluminum alloys based on the Al-Si phase diagram are the ones, which are used due to their hardness, tensile strength and elongation properties and higher castability. Also, this was provided by the $\mathrm{Si}$ addition to the $\mathrm{AlSi}_{9} \mathrm{Cu}_{3}$ aluminum cast alloy, which shows good toughness, high strength, excellent corrosion, and high damage tolerance capability and fatigue resistance [8-11]. The final mechanical properties of $\mathrm{AlSi}_{9} \mathrm{Cu}_{3}$ components are a combination between the alloying elements and molten metal temperature, composition, casting processes, degasification procedure, temperature evolution, and heat treatment after casting [12-18].

The composition in alloying elements such as $\mathrm{Si}, \mathrm{Cu}, \mathrm{Mg}, \mathrm{Mn}$, and Fe have a significant role in the shape, distribution of the Silicon particles as well as in the formation and shape of intermetallic compounds (e.g., $\mathrm{Mg}_{2} \mathrm{Si}, \mathrm{Al}_{2} \mathrm{Cu}, \beta-\mathrm{Al}_{5} \mathrm{FeSi}, \mathrm{Al}_{2} \mathrm{CuMg}, \mathrm{AlFeMn}, \mathrm{Al}_{17} \mathrm{Cu}_{4} \mathrm{Ni}, \alpha-\mathrm{Al}_{15}(\mathrm{FeMn})_{3} \mathrm{Si}_{2}$, $\mathrm{Al}_{15} \mathrm{Cu}_{2} \mathrm{Mg}_{8} \mathrm{Si}_{6}$ ), which has substantial impact on the mechanical properties, they are partially soluble in the $\alpha$-Al matrix Copper. Further, this fact increases the tensile strength, hardness and also reduces the elongation properties of the aluminum alloys, intermetallic particles of the shape/distribution, which can lead to the development of stress incompatibilities between the brittle precipitates and this Al-Si matrix (metal composites). The accumulation and formation of stress lead to particle fracture that results in stress relaxation with $\mathrm{Al}$ surrounding matrix transferring the load to neighboring particles. Therefore, the mentioned alloy characteristics hinder the forecasting of the mechanical properties of the $\mathrm{AlSi}_{9} \mathrm{Cu}_{3}$ alloys, as well as their mechanical behavior modeling.

The work in [19] established the influence of the thickness of the wear-resistant layer of the $\mathrm{Zr}-\mathrm{ZrN}-(\mathrm{Zr}, \mathrm{Al}, \mathrm{Si}) \mathrm{N}$ nanolayer composite coating on the values of residual stress and the nature of coating wear. The authors in [20] devised a superhydrophobic coating, which was prepared from recyclable materials to provide a sustainable and low-cost solution, with potential applications to 
large surfaces in a marine environment. Moreover, the work in [21] discussed the coatings deposited via pulsed cathodic arc evaporation (PCAE) of a $\mathrm{TiC}-\mathrm{NiCr}-\mathrm{Eu}_{2} \mathrm{O}_{3}$ cathode fabricated by the powder metallurgy method. The deposition was carried out in different gas media, including Ar, $\mathrm{N}_{2}$, and $\mathrm{C}_{2} \mathrm{H}_{4}$. The research in [22] devised the concept of combining the traditional electrochemical tests, including the Tafel extension method and Mott-Schottky fitting, spectroscopic ellipsometry (SE) and a micro-region analysis technique that is an integrated system of a scanning reference electrode technique and scanning tunneling microscope (SRET/STM).

Further, the changes in properties of the oxide film that got formed on the surface of the U-0.79 wt.\% Ti alloy (U-Ti alloy in short) in $0.1 \mathrm{M} \mathrm{NaNO}_{3}$ were carefully investigated concerning the changes in the $\mathrm{pH}$ value. The work [23] elucidated on the fabrication of photo catalysis-enhanced surface deposition on titanium surfaces. Moreover, the authors in [24] investigated the pristine thermal spray coatings using the pull-off adhesion test to understand the adhesion strength, and Vickers hardness was measured for the mechanical properties of the three coatings.

In this research, $\mathrm{AlSi}_{9} \mathrm{Cu}_{3}$ alloy was fabricated through the die-casting method, and microstructures of as-cast and post-coating were recorded, and electrochemical behavior was investigated in detail. The stability of coating strength and thickness measurement were also discussed. In the present investigation, synthesis of $\mathrm{AlSi}_{9} \mathrm{Cu}_{3}$ by casting route and study the microstructure of cast $\mathrm{AlSi}_{9} \mathrm{Cu}_{3}$ and then various coatings were performed on die-casted $\mathrm{AlSi}_{9} \mathrm{Cu}_{3}$ alloy (powder coat and ED coat). The stability of coating strength and thickness measurement and its electrochemical behavior on the surface coated Al alloy die-castings were investigated.

\section{Experimental Methods}

The experimental alloys were produced through the gravity die-casting process (SWAM EQUIP, Chennai, Tamil Nadu, India) using the cylindrical harden steel molds with a dimension of $30 \mathrm{~mm}$ diameter and $250 \mathrm{~mm}$ height (Figure 1). Since the casting has a larger length, two dies have been used, the lower die was assembled on a supporting unit and then the upper die was stacked over the lower die. The mold material was coated by using high-temperature Wolfram coating and then the mold was air-dried. Before die-casting the mold, necessary casting tools were preheated to $180{ }^{\circ} \mathrm{C}$. About $1000 \mathrm{~g}$ of $\mathrm{AlSi}_{9} \mathrm{Cu}_{3}$ alloy was produced via in gravity die-casting, which is available in NIT Trichy, Tamil Nadu, India. The liquid metal was allowed to remove the dross at $685{ }^{\circ} \mathrm{C}$ and then the hexachloroethane $\left(\mathrm{C}_{2} \mathrm{Cl}_{6}\right)$ tablet was added for degasifying the melt. After completion of degassing, the furnace temperature was reached to $750{ }^{\circ} \mathrm{C}$ to allow the alloy to become homogeneous by using a stirrer, and then the liquid metal was poured into the lower mold.

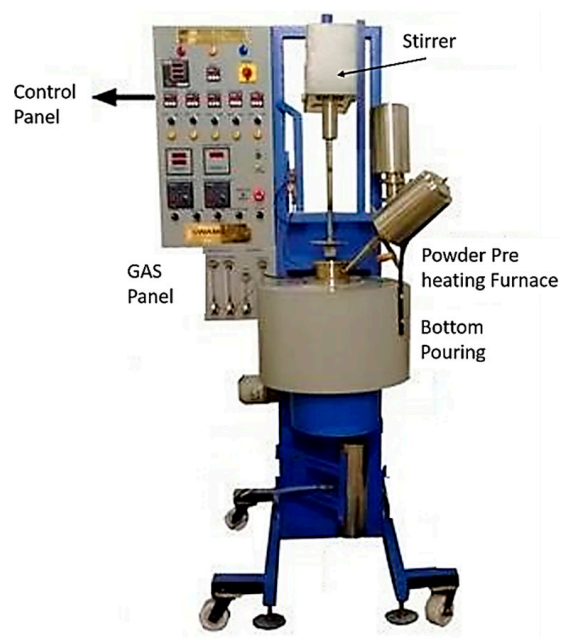

(a)

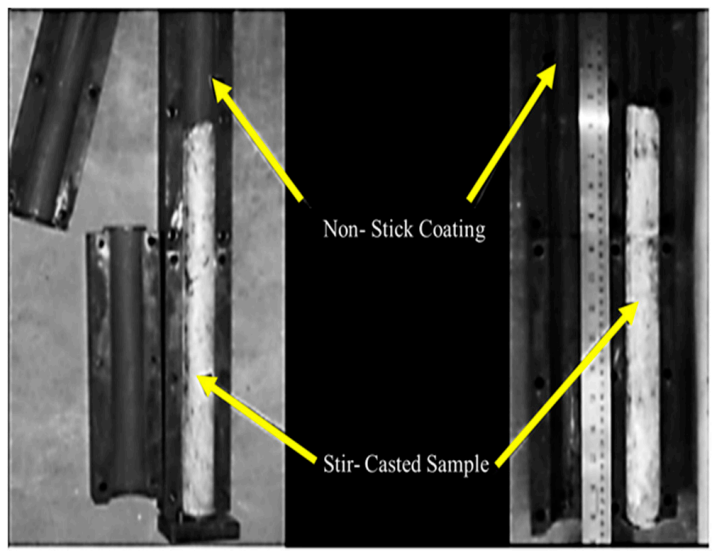

(b)

Figure 1. Die-casting furnace diagram—Preparation of casting: (a) Stir-casting machine, (b) Stir-casted sample. 


\subsection{Preparation of Powder Coating}

Powder coating with no emission of volatile organic compounds (VOCs) is a clean process; the process flow for preparation of powder coating is shown in Figure 2. The chemical composition of $\mathrm{AlSi}_{9} \mathrm{Cu}_{3}$ is listed in Table 1, which is confirmed by using Optical Emission Spectroscopy, Test Lab, Coimbatore, Tamil Nadu, India.

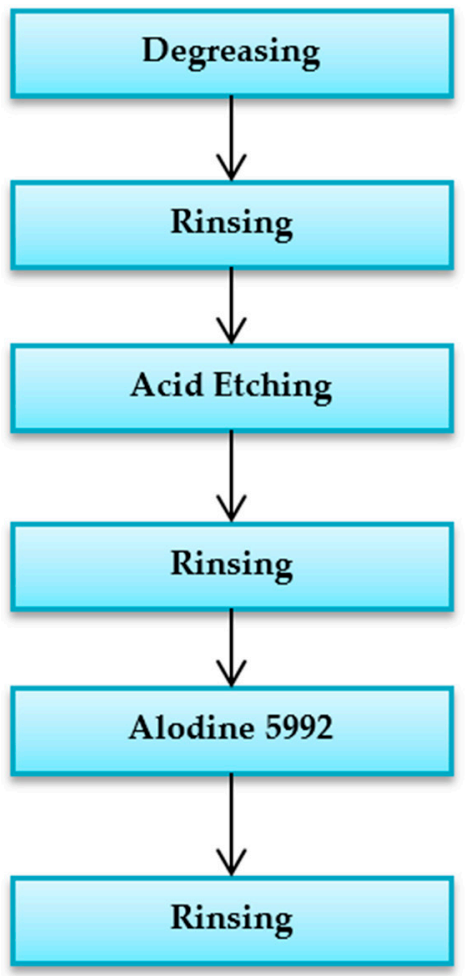

\section{Method:}

For achieving coating thickness evenly, utilize both the

directions one by one for obtaining (60-80 microns

\section{thickness)}

First pass (20 microns) - Upwards and Downwards

Second Pass (20 microns) - Leftwards and Rightwards

Third pass (20 microns) - Upwards and Downwards

Fourth Pass (20 microns) - Leftwards and Rightwards

Figure 2. Flow diagram-Preparation of powder coating.

Table 1. Chemical composition of $\mathrm{AlSi}_{9} \mathrm{Cu}_{3}$.

\begin{tabular}{ccccccccccccc}
\hline Element & $\mathbf{S i}$ & $\mathbf{C u}$ & $\mathbf{F e}$ & $\mathbf{M n}$ & $\mathbf{N i}$ & $\mathbf{C r}$ & $\mathbf{T i}$ & $\mathbf{P b}$ & $\mathbf{M g}$ & $\mathbf{Z n}$ & $\mathbf{S n}$ & $\mathbf{A l}$ \\
\hline Content wt. $\%$ & 9 & 3 & 1.3 & 0.55 & 0.55 & 0.15 & 0.25 & 0.35 & 0.55 & 1.2 & 0.15 & Bal. \\
\hline
\end{tabular}

\subsection{Preparation of ED Coating}

The process works on the principle of opposite attract, using electrical current to deposit the paint, the flow chart of preparation of ED coating is shown in Figure 3. The surface coating on die-casted $\mathrm{AlSi}_{9} \mathrm{Cu}_{3}$ alloy was developed, and specific acrylic paint ED coat, 2-coat polyester without primer \& 3 -coat polyester with epoxy primer powder coatings were applied on the $\mathrm{AlSi}_{9} \mathrm{Cu}_{3}$ alloy. The above sequence was followed for applying a coating from step 1 to step 3. Further, the ED charged particles from the paint emulsion under electrical forces, move to anode or cathode. The pigments and resin base of the paint wanders towards the body surfaces by D.C established through the bath. The undeposited material is rinsed. Ultra-filtration is used for ED paint ingredients separations, and recovery of paints deposited film after storing becomes a harder, durable, and polymeric film. The time difference lag is clearly recorded with the help of computer processing between the transmitting signal and the receiving signal from the workpiece, as shown in Figure 4. 


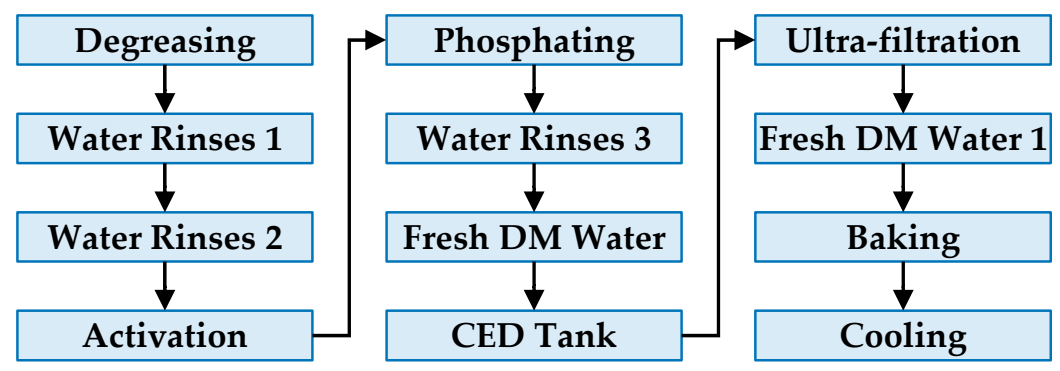

Figure 3. Flow diagram-Preparation of electrodeposition (ED)coating.

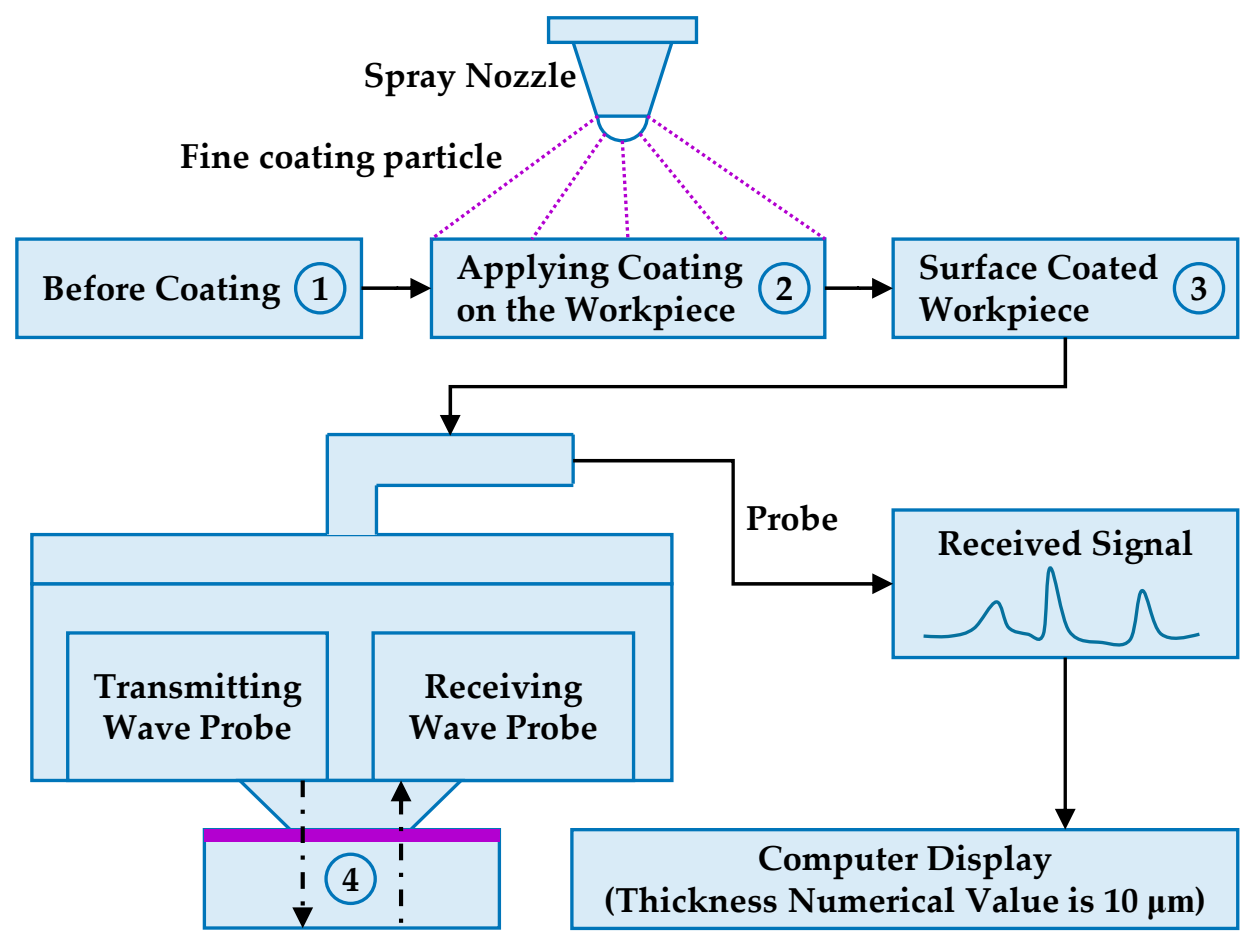

Figure 4. Coating thickness measurement by the ultrasonic probe sensors.

\subsection{The Sample Prepared for PD and EIS}

All EIS tests were carried out in a standard three-electrode cell by the usage of the platinum electrode and saturated calomel electrode (SCE) as auxiliary and reference electrodes, respectively. The tests were carried out at room temperature $\left(26^{\circ} \mathrm{C}\right)$. The photograph of the sample after coating was prepared for PD, and the EIS test was shown in Figure 5.

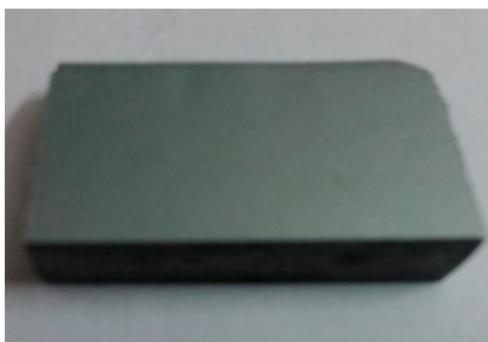

(a)

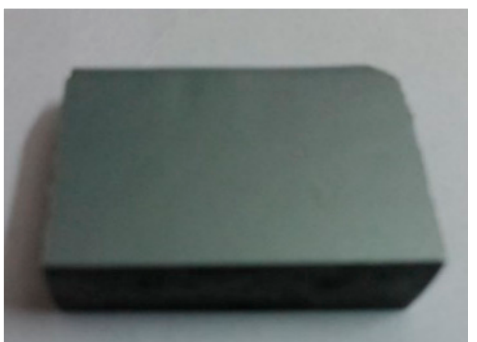

(b)

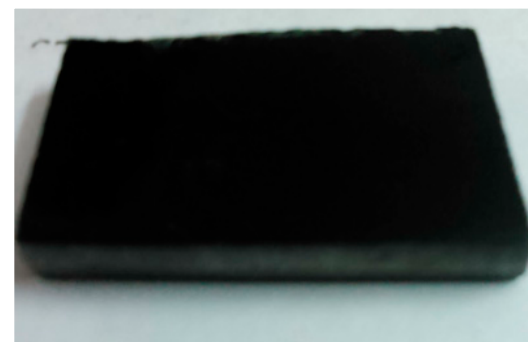

(c)

Figure 5. (a) Acrylic paint ED coat; (b) 2-coat polyester without primer; (c) 3-coat polyester with epoxy primer-coating thickness measurement. 


\section{Results and Discussion}

The performance of various coating on $\mathrm{AlSi}_{9} \mathrm{Cu}_{3}$ (powder coat and $\mathrm{ED}$ coat) was observed, and the thickness of the coating measured through the DIC Leica optical microscope, as shown in Figure 6. The potentiodynamic anodic polarization tests were carried out, as shown in Figure 7. It is established that the current decreases with increased corrosion resistance. Even though powder coatings exhibit superior performance in many aspects, it performs better when compared to liquid coatings. Also, due to sterner environmental regulations, powder coatings are highly preferred than liquid coatings, and it has received more considerable attention from the manufacturing industry. The main advantage of the powder coating process is to collect over-sprayed material that did not adhere to the workpiece and recycle it as reclaimed powder. The amount of reclaimed powder produced in a powder coating operation depends upon factors such as the size $(20 \mu \mathrm{m})$ and shape of the workpiece, the powder coating material, the coating equipment, the equipment settings, and application environments. Powder samples used for the investigation are polyester or epoxy powder, which is then heated to fuse into a protective layer. The influence of the coating thickness plays a significant role in the success of corrosion resistance developed on the surface of the workpiece. The ultrasonic probe is deployed for measuring the coating thickness, and it is analyzed with the help of two probes. One of the probes is called transmitting, and another one is the receiving and subsequently handling the signals from the reflecting peak through the bottom of the workpiece. This probe is used to extensively measure the coating thickness of the workpiece with the help of the transmitting and receiving probe. Acrylic paint ED coat possesses slightly better corrosion resistance than 2-coat polyester without primer. The polymer coatings on $\mathrm{Al}$ alloy substrates were determined from potentiodynamic polarization measurements. The values of $E_{\text {corr }}, I_{\text {corr }}$, Tafel slopes $\beta_{\mathrm{a}}, \beta_{\mathrm{c}}$, and polarization resistance $\left(R_{\mathrm{p}}\right)$ and corrosion rate (CR) obtained from this measurement were summarized in Table 2 . The potentiodynamic polarization curve for 3-coat polyester with epoxy primer coated $(250 \mu \mathrm{m}$ thick). Figure 7 established that the $I_{\text {corr }}$ decreases from $0.0009 \mathrm{~mA} / \mathrm{cm}^{2}$ for bare metal to $3.084 \times 10^{-9} \mathrm{~mA} / \mathrm{cm}^{2}$ for 3-coat polyester with epoxy primer coating. The $I_{\text {corr }}$ value also includes the contribution resulted from the oxidation of the polymer coating since these are not steady-state measurements-the $E_{\text {corr }}$ increases from-748 mVSCE for bare metal to $422.69 \mathrm{mVSCE}$ for 3-coat polyester with epoxy primer coating. The CR of the bare metal is significantly reduced as a result of the increases in the $I_{\text {corr }}$ or due to the corresponding decreases in the $E_{\text {corr }}$. The corrosion rate of 3-coat polyester with epoxy primer coating is found to be $4.12 \times 10^{-9} \mathrm{mpy}$, which is lower than that of observed for bare metal.

Table 2. Polarization parameters.

\begin{tabular}{ccccccc}
\hline $\begin{array}{c}\text { Experimental } \\
\text { Sample }\end{array}$ & $\beta_{\mathbf{a}}(\mathbf{m V})$ & $\beta_{\mathbf{c}}(\mathbf{m V})$ & $\begin{array}{c}I_{\mathbf{c o r r}} \\
\left(\mathbf{m A} / \mathbf{c m}^{2}\right)\end{array}$ & $\begin{array}{c}E_{\text {corr }} \\
(\mathbf{m V S C E})\end{array}$ & $\begin{array}{c}\text { Corrosion } \\
\text { Rate }(\mathbf{m p y})\end{array}$ & $\begin{array}{c}\text { Polarization } \\
\text { Resistance } \\
\boldsymbol{R}_{\mathbf{p}}\left(\mathbf{k} \boldsymbol{\Omega} \cdot \mathbf{c m}^{2}\right)\end{array}$ \\
\hline Acrylic paint ED coat & 15.07 & 17.09 & 0.00065 & -736 & $1.18 \times 10^{-4}$ & 5.3 \\
\hline $\begin{array}{c}\text { 2-coat polyester } \\
\text { without primer }\end{array}$ & 23.25 & 16.03 & 0.00072 & -738 & $5.73 \times 10^{-4}$ & 5.7 \\
\hline $\begin{array}{c}\text { 3-coat polyester with } \\
\text { epoxy primer }\end{array}$ & 23.536 & 21.99 & $3.084 \times 10^{-9}$ & 422.69 & $4.12 \times 10^{-9}$ & 1.6 \\
\hline
\end{tabular}

Table 3 revealed that EIS results. Higher values of $R_{\mathrm{ct}}$ and lower value of $C_{\mathrm{dl}}$ indicated excellent corrosion performance. The bode plot is a graph between impedance versus frequency. The coating defects and other changes in surface area were given a high-frequency region. Bode plot lines suggested that Acrylic paint ED coat exhibited better corrosion resistance, as shown in Figure 8. 


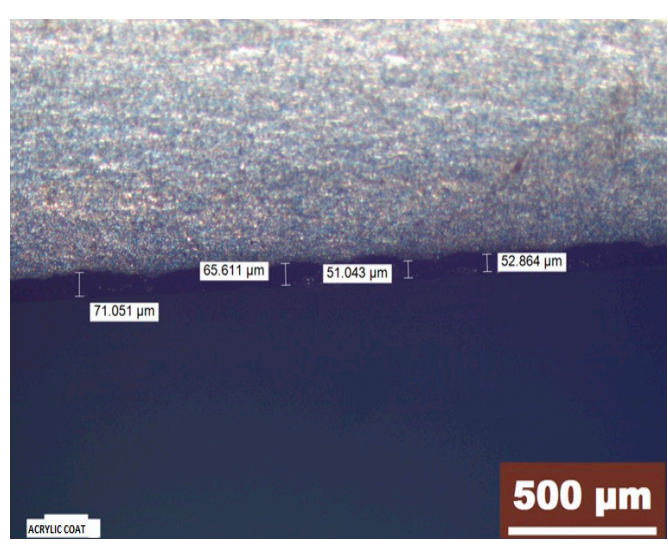

(a)

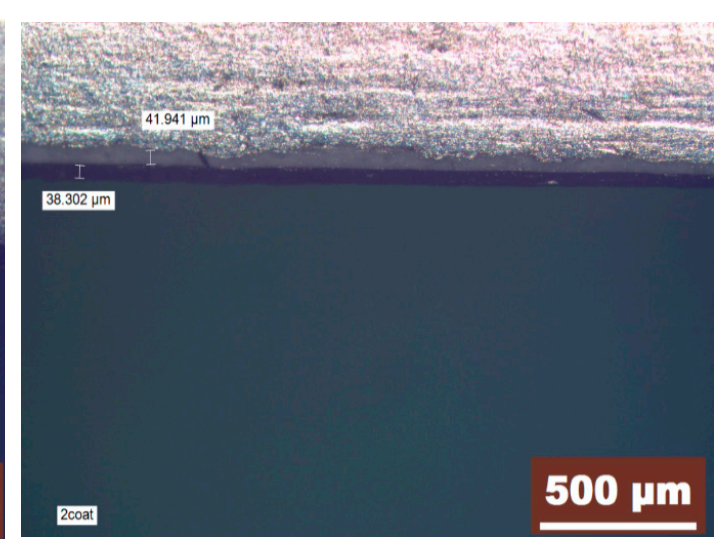

(b)

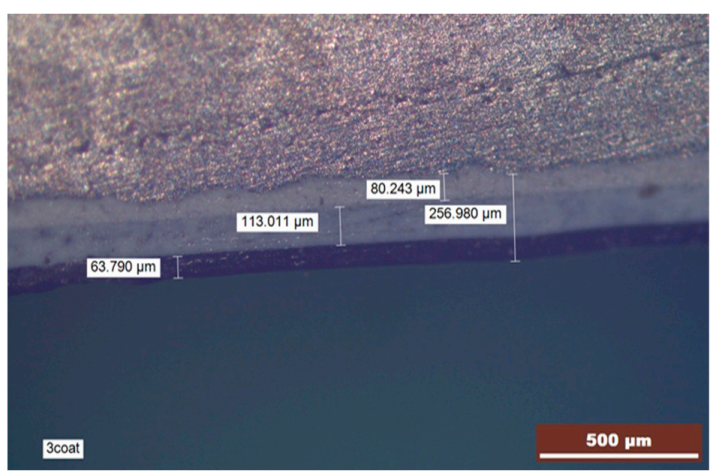

(c)

Figure 6. Microstructure images of the coating thickness: (a) Acrylic paint ED coat; (b) 2-coat polyester without primer; (c) 3-coat polyester with epoxy primer.

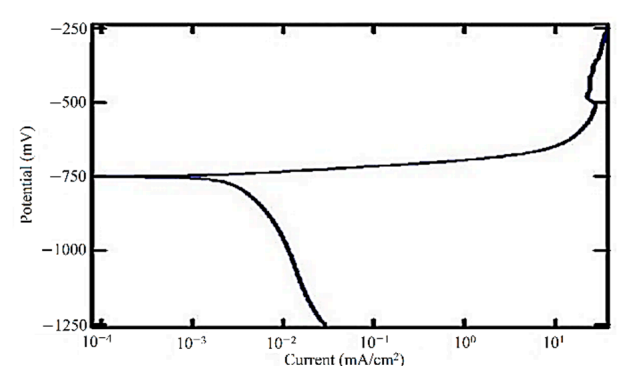

(a)

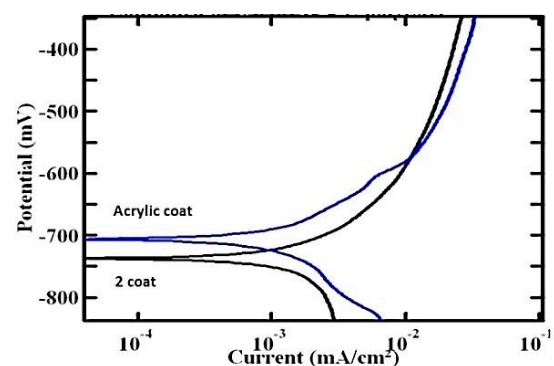

(b)

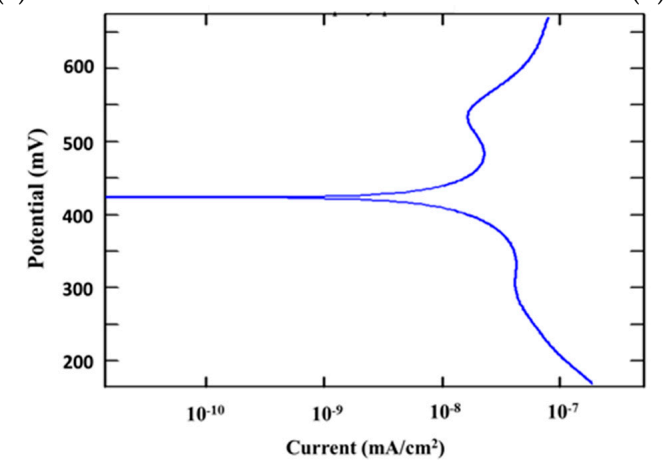

(c)

Figure 7. Current versus potential graph for measuring corrosion rate: (a) Acrylic paint ED coat; (b) 2-coat polyester without primer; (c) 3-coat polyester with epoxy primer. 
Table 3. Electrochemical impedance spectroscopy results.

\begin{tabular}{ccc}
\hline Experimental Sample & $\boldsymbol{R}_{\mathrm{ct}}\left(\boldsymbol{\Omega} \cdot \mathbf{c m}^{2}\right)$ & $\boldsymbol{C}_{\mathrm{dl}}(\mu \mathrm{F} \cdot \mathrm{cm})$ \\
\hline Acrylic paint ED coat & $8.89 \times 10^{9}$ & $1.009 \times 10^{-11}$ \\
\hline 2-coat polyester without primer & $5.569 \times 10^{9}$ & $3.723 \times 10^{-11}$ \\
\hline 3-coat polyester with epoxy primer & $2.486 \times 10^{9}$ & $2.694 \times 10^{-11}$ \\
\hline
\end{tabular}

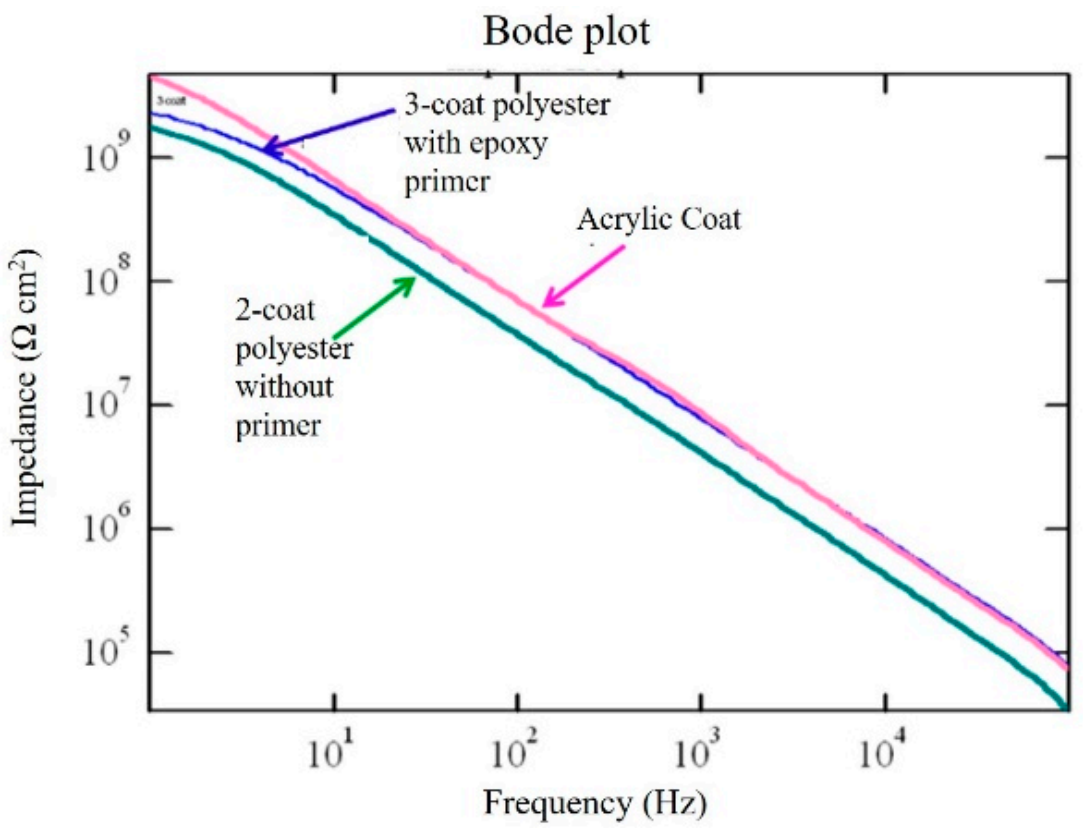

Figure 8. Bode plot.

In general, the higher the impedance denotes higher corrosion resistance. Numerical fitting using the equivalent circuit was done first, and then the interpretation of EIS was carried out. The magnitude of the impedance signal gets increased at frequencies lower than $0.1 \mathrm{~Hz}$; further, the phase angle becomes positive, and these data fall in the first quadrant of the Nyquist plot, as shown in Figure 9. These plots were fitted to the equivalent circuit, as shown in Figure 9. The acrylic paint ED coated specimens were exposed with a $3.5 \% \mathrm{NaCl}$ test solution, offered the highest resistance of $2.50 \times 10^{9} \Omega \cdot \mathrm{cm}^{2}$. Similarly, 2-coat polyester without primer and 3-coat polyester with epoxy primer coating specimens exhibited resistance of $1.35 \times 10^{9}$ and $1.00 \times 10^{9} \Omega \cdot \mathrm{cm}^{2}$.

The coating resistance of the different samples is given in Table 4. The salt spray corrosion testing (SSCT ) samples were suspended in a cabinet with a nylon thread and exposed to a $3.5 \mathrm{wt} . \% \mathrm{NaCl}$ solution, the SSCT environment conducted as per ASTM B117 standard. The temperature inside the cabinet was $35 \pm 2{ }^{\circ} \mathrm{C}$, and the air pressure of the atomized saline solution was maintained in the range of $69-172 \mathrm{KPa}$. After the SSCT treatment, the samples were dried in warm ambient air and after that sealed up immediately.

Table 4. Sample vs. Coating resistance.

\begin{tabular}{cc}
\hline Experimental Sample & Coating Resistance $\left(\mathbf{Z}^{\prime} \mathbf{\Omega} \cdot \mathbf{c m}^{\mathbf{2}}\right)$ \\
\hline Acrylic paint ED coat & $2.50 \times 10^{9}$ \\
\hline 2-coat polyester without primer & $1.35 \times 10^{9}$ \\
\hline 3-coat polyester with epoxy primer & $1.00 \times 10^{9}$ \\
\hline
\end{tabular}




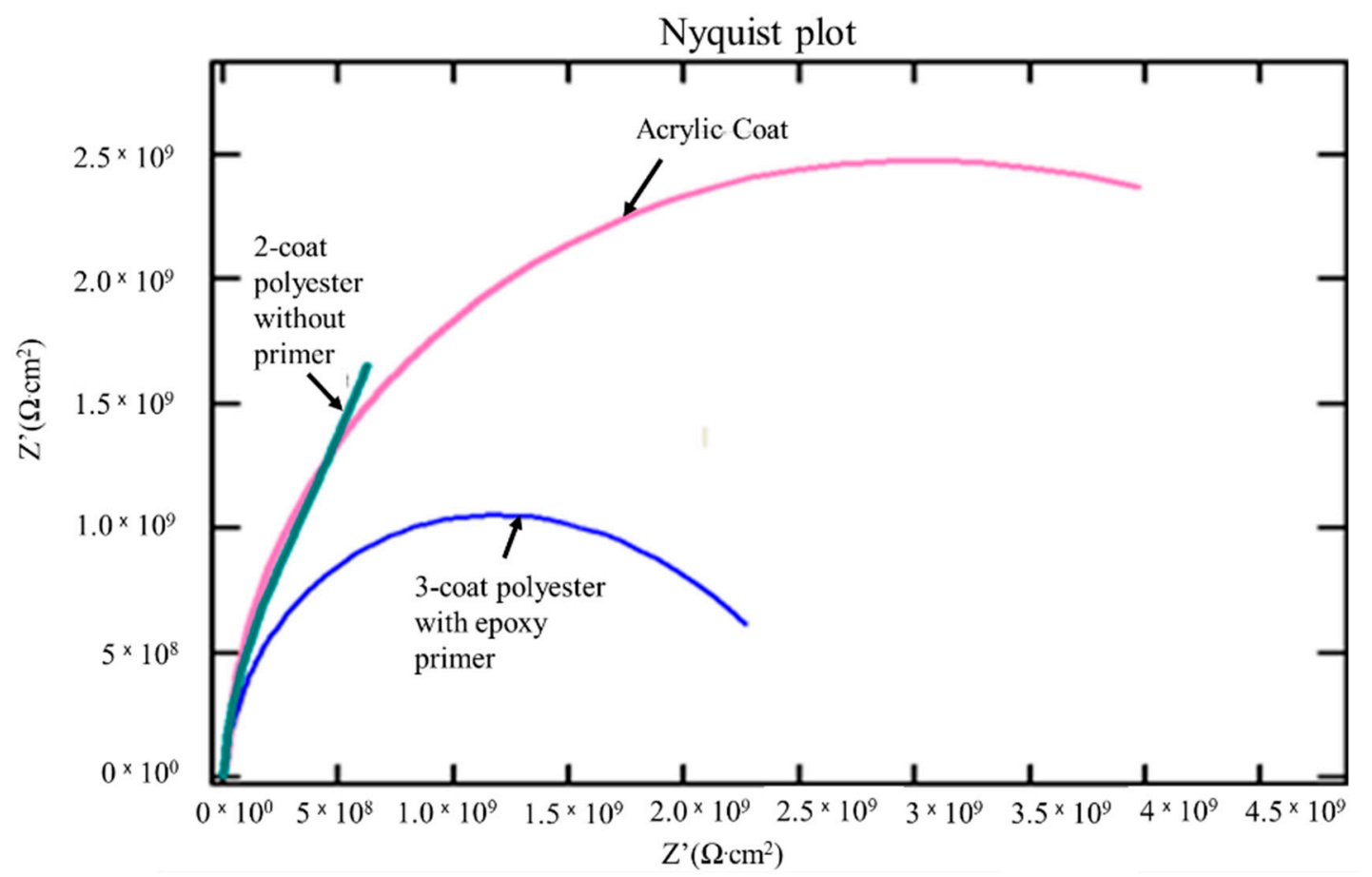

Figure 9. Nyquist plot.

Filiform Corrosion

The worm-like tracks tunneling under a surface coating was observed in Figures 10-12. From these figures, it was evident that anodization takes place on the aluminum surface; the corrosive attack was observed at the metal/coating interface. Generally, this kind of corrosion happens due to improper/damaged surface coating. In this experimental work, it is showed that based on the SST, acrylic paint ED coatings exhibited better corrosion resistance than the others (2-coat polyester without primer and 3-coat polyester with epoxy primer coatings). Filiform corrosion occurs due to physical sample preparation. Typical characteristics for filiform corrosion are that it occurs at a relative humidity between $40 \%$ and $90 \%$. Filaments follow pre-existing directionality.

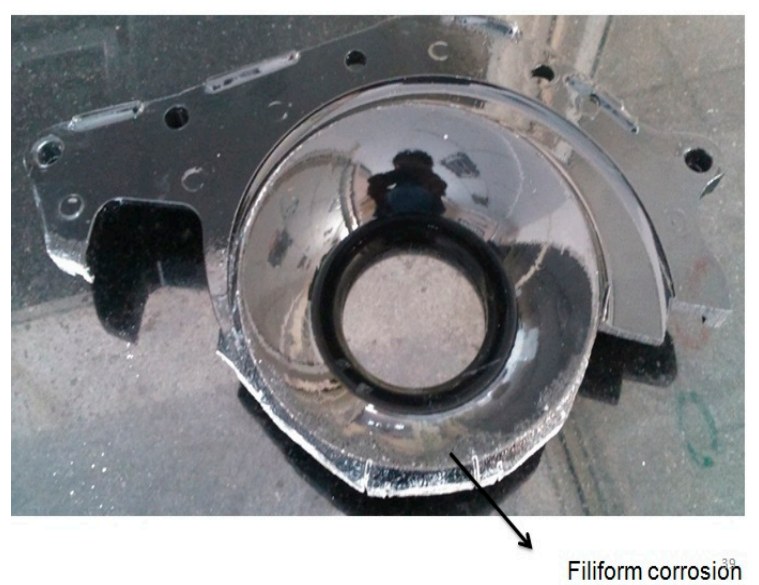

Figure 10. Acrylic paint ED coat. 


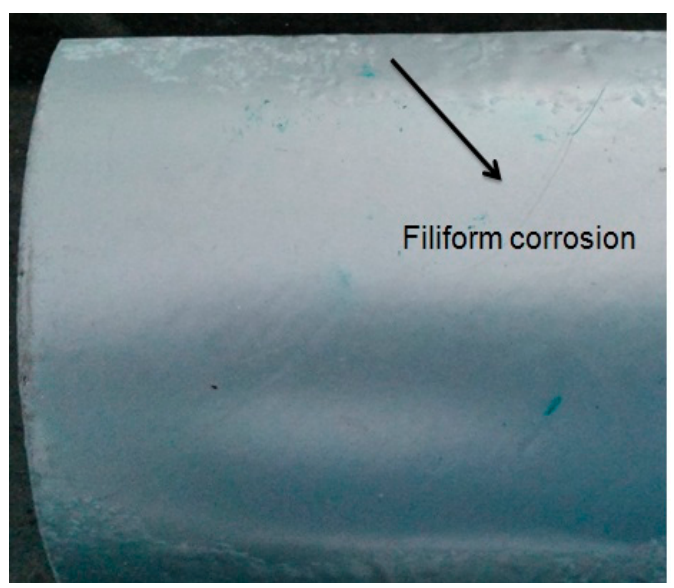

Figure 11. 2-coat polyester without primer.

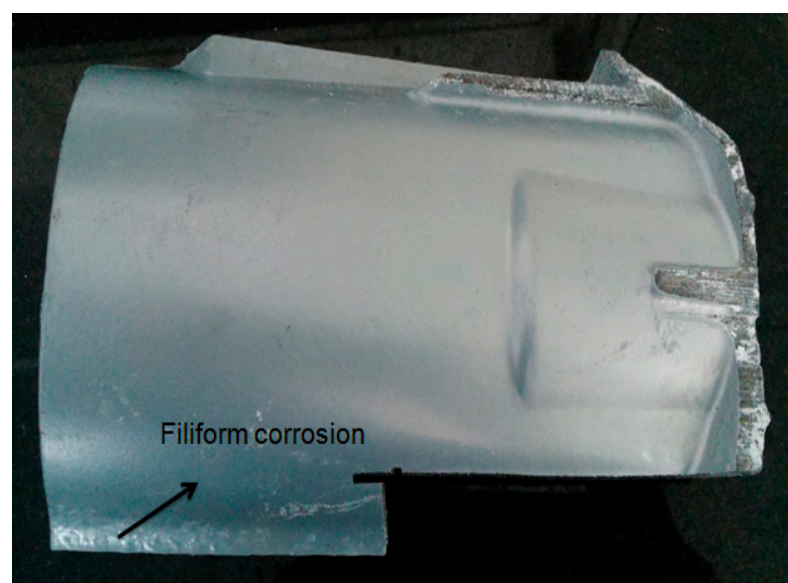

Figure 12. 3-coat polyester with epoxy primer.

Figure 13 illustrates the corroded surface morphology after the salt spray test in a $3.5 \% \mathrm{NaCl}$ solution. The macrostructures were observed after the complete removal of corrosion products in (a) Acrylic paint ED coat (b) 2-coat polyester without primer (c) 3-coat polyester with epoxy primer were cleaned according to the procedure of ASTM G1-03. Figure 13c is an example of the low corrosion attack in $3.5 \% \mathrm{NaCl}$ salt spray test for 3-coat polyester with epoxy primer sample. After exposed to $72 \mathrm{~h}$ of salt spraying, 3-coat polyester with epoxy primer coated sample exhibits an oxide film on the surface that temporarily resists the local corrosion attack. Table 5 illustrates the corrosion rate of samples after $24,48,72$, and 96 h of salt spray test.
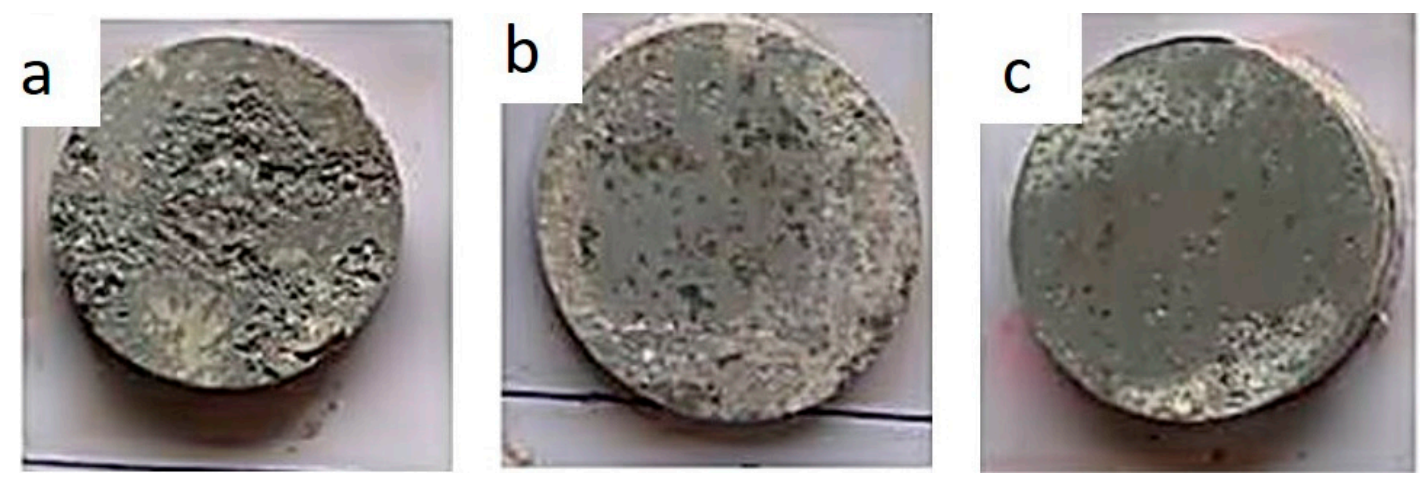

Figure 13. Surface macro-morphology images after salt spray test in $3.5 \% \mathrm{NaCl}$ solution: (a) Acrylic paint ED coat; (b) 2-coat polyester without primer; (c) 3-coat polyester with epoxy primer. 
Table 5. Corrosion rate of samples after $24,48,72$, and $96 \mathrm{~h}$ of salt spray test.

\begin{tabular}{ccccc}
\hline \multirow{2}{*}{ Experimental Sample } & \multicolumn{4}{c}{ Corrosion Rate (mmpy) } \\
\cline { 2 - 5 } & After $\mathbf{2 4} \mathbf{h}$ & After $\mathbf{4 8} \mathbf{h}$ & After $\mathbf{7 2} \mathbf{~ h}$ & After $\mathbf{9 6} \mathbf{~}$ \\
\hline Acrylic paint ED coat & 10.12 & 12.01 & 14.13 & 14.50 \\
2-coat polyester without primer & 9.43 & 10.31 & 12.14 & 13.13 \\
3-coat polyester with epoxy primer & 7.21 & 7.51 & 8.00 & 8.00 \\
\hline
\end{tabular}

\section{Conclusions}

Based on the systematic study, the following are the main conclusions. The different types of coatings such as Acrylic paint ED coat, 2-coat polyester without primer, and 3-coat polyester with epoxy primer powder were carried out on the surface of die-casted $\mathrm{AlSi}_{9} \mathrm{Cu}_{3}$ alloy. Further, the stability of coating strength and thickness was observed on as-cast $\mathrm{AlSi}_{9} \mathrm{Cu}_{3}$ alloy and after coating. Based on the assessment of electrochemical corrosion behavior of as-cast and coated $\mathrm{AlSi}_{9} \mathrm{Cu}_{3}$ alloy, it was found that acrylic paint ED coatings exhibited better corrosion resistance than 2-coat polyester without primer and 3-coat polyester with epoxy primer coatings. The acrylic paint ED coatings exhibited higher resistance in $\mathrm{AC}$ and lowered resistance in DC; on the other hand, other coatings exhibited lower resistance in $\mathrm{AC}$ and higher resistance in DC. In future work, advanced digital-driven transformation technologies (Industry X.0), including artificial intelligence approaches, shall be deployed for overcoming the challenges faced due to corrosion and related issues [25-36], thereby improving the quality of the coating longevity. The salt spray test results confirm that 3-coat polyester with epoxy primer coated sample exhibits an oxide film on the surface that temporarily resist the local corrosion attack.

Author Contributions: Conceptualization, Y.-C.H., S.K.S., M.S. and K.S.; methodology, S.K.S. and M.S.; software, K.S.; validation, Y.-C.H., S.K.S. and M.S.; formal analysis, S.K.S.; investigation, Y.-C.H., S.K.S., M.S. and K.S.; resources, M.S., Y.-C.H. and K.S.; data curation, K.S.; writing-Original draft preparation, Y.-C.H., S.K.S., M.S. and K.S.; writing-Review and editing, S.K.S., K.S. and S.N.; visualization, S.K.S. and Y.-C.H.; supervision, Y.-C.H.; project administration, Y.-C.H.; funding acquisition, Y.-C.H. All authors have read and agreed to the published version of the manuscript.

Funding: This research was partially funded by the Ministry of Science and Technology of Taiwan, grant number MOST 108-2622-E-197-001-CC2; MOST 108-2221-E-197-027.

Conflicts of Interest: The authors declare no conflicts of interest.

\section{References}

1. Johansen, H.D.; Brett, C.M.A.; Motheo, A.D.J. Corrosion protection of aluminium alloy by cerium conversion and conducting polymer duplex coatings. Corros. Sci. 2012, 63, 342-350. [CrossRef]

2. Baldissera, A.F.; Ferreira, C.A. Coatings based on electronic conducting polymers for corrosion protection of metals. Prog. Org. Coat. 2012, 75, 241-247. [CrossRef]

3. Zelinka, S.L.; Ortiz-Candelaria, L.; Stone, D.S.; Rammer, D.R. Electrochemical impedance spectroscopy (EIS) as a tool for measuring corrosion of polymer-coated fasteners used in treated wood. For. Prod. J. 2009, 59, 77-82.

4. Frankel, G.S.; Papavinasam, S.; Berke, N.; Brossia, S.; Dean, S. Electrochemical techniques in corrosion: Status, limitations, and needs. J. ASTM Int. 2008, 5, 101241. [CrossRef]

5. Kumar, S.A.; Alagar, M.; Mohan, V. Studies on corrosion-resistant behavior of siliconized epoxy interpenetrating coatings over mild steel surface by electrochemical methods. J. Mater. Eng. Perform. 2002, 11, 123-129. [CrossRef]

6. Mansfeld, F.; Han, L.T.; Lee, C.C.; Zhang, G. Evaluation of corrosion protection by polymer coatings using electrochemical impedance spectroscopy and noise analysis. Electrochim. Acta 1998, 43, 2933-2945. [CrossRef]

7. Calle, L.; MacDowell, L.G. Corrosion protection of launch infrastructure and flight hardware at the Kennedy Space Center. In Proceedings of the Space Congress, Cape Canaveral, FL, USA, 2 May 2002.

8. Brickweg, L.J.; Floryancic, B.R.; Sapper, E.D.; Fernando, R.H. Shear-induced 1-D alignment of alumina nanoparticles in coatings. J. Coat. Technol. Res. 2007, 4, 107-110. [CrossRef] 
9. Shabestari, S.G.; Gruzleski, J.E. The effect of solidification condition and chemistry on the formation and morphology of complex intermetallic compounds in aluminium-silicon alloys. Cast Met. 1994, 6, 217-224. [CrossRef]

10. Gustafsson, G.; Thorvaldsson, T.; Dunlop, G.L. The influence of Fe and Cr on the microstructure of cast Al-Si-Mg alloys. Metall. Trans. A 1986, 17, 45-52. [CrossRef]

11. Makhlouf, M.M.; Apelian, D.; Wang, L. Microstructures and Properties of Aluminum Die Casting Alloys; USDOE Idaho Operations Office: Idaho Falls, ID, USA, 1998. [CrossRef]

12. Wranglen, G. An Introduction to Corrosion and Protection of Metals, 1st ed.; Springer: Dordrecht, The Netherlands, 1985.

13. Mansfeld, F.; Bertocci, U. (Eds.) STP727-EB Electrochemical Corrosion Testing; ASTM International: West Conshohocken, PA, USA, 1981. [CrossRef]

14. Jones, F.N.; Nichols, M.E.; Pappas, S.P. Organic Coatings: Science and Technology, 4th ed.; John Wiley \& Sons: Hoboken, NJ, USA, 2017.

15. Hirayama, R.; Haruyama, S. Electrochemical impedance for degraded coated steel having pores. Corrosion 1991, 47, 952-958. [CrossRef]

16. Rammelt, U.; Reinhard, G. Characterization of active pigments in damage of organic coatings on steel by means of electrochemical impedance spectroscopy. Prog. Org. Coat. 1994, 24, 309-322. [CrossRef]

17. Mansfeld, F.; Tsai, C.H. Determination of coating deterioration with EIS: I. basic relationships. Corrosion 1991, 47, 958-963. [CrossRef]

18. Sekine, I. Recent evaluation of corrosion protective paint films by electrochemical methods. Prog. Org. Coat. 1997, 31, 73-80. [CrossRef]

19. Vereschaka, A.; Volosova, M.; Chigarev, A.; Sitnikov, N.; Ashmarin, A.; Sotova, C.; Bublikov, J.; Lytkin, D. Influence of the thickness of a nanolayer composite coating on values of residual stress and the nature of coating wear. Coatings 2020, 10, 63. [CrossRef]

20. Ferrari, M.; Benedetti, A.; Cirisano, F. Superhydrophobic coatings from recyclable materials for protection in a real sea environment. Coatings 2019, 9, 303. [CrossRef]

21. Kiryukhantsev-Korneev, P.; Sytchenko, A.; Sheveyko, A.; Vorotilo, S. Structure and properties of protective coatings deposited by pulsed cathodic arc evaporation in $\mathrm{Ar}, \mathrm{N}_{2}$, and $\mathrm{C}_{2} \mathrm{H}_{4}$ environments using the $\mathrm{TiC}-\mathrm{NiCr}-\mathrm{Eu}_{2} \mathrm{O}_{3}$ cathode. Coatings 2019, 9, 230. [CrossRef]

22. Cai, D.; Zhang, D.; Chen, X.; Wu, H.; Wang, M.; Sang, G.; Li, Y. Influences of pH values' changes on the oxide film of U-0.79 wt.\% Ti alloy in aqueous solution-A combined study of traditional electrochemical tests and scanning reference electrode technique. Coatings 2019, 9, 224. [CrossRef]

23. Su, C.-Y.; Zhou, Q.; Zou, C.-H. Surface deposition on titania in a physiological solution with ultraviolet irradiation in situ and effect of heat treatment. Coatings 2019, 9, 80. [CrossRef]

24. Yung, T.-Y.; Chen, T.-C.; Tsai, K.-C.; Lu, W.-F.; Huang, J.-Y.; Liu, T.-Y. Thermal spray coatings of Al, ZnAl and inconel 625 alloys on SS304L for anti-saline corrosion. Coatings 2019, 9, 32. [CrossRef]

25. Katić, J.; Šarić, A.; Despotović, I.; Matijaković, N.; Petković, M.; Petrović, Ž. Bioactive coating on titanium dental implants for improved anticorrosion protection: A combined experimental and theoretical study. Coatings 2019, 9, 612. [CrossRef]

26. Conradi, M.; Sever, T.; Gregorčič, P.; Kocijan, A. Short- and long-term wettability evolution and corrosion resistance of uncoated and polymer-coated laser-textured steel surface. Coatings 2019, 9, 592. [CrossRef]

27. Panjan, P.; Drnovšek, A.; Gselman, P.; Čekada, M.; Panjan, M.; Bončina, T.; Kek Merl, D. Influence of growth defects on the corrosion resistance of sputter-deposited TiAlN hard coatings. Coatings 2019, 9, 511. [CrossRef]

28. Monticelli, C.; Fantin, G.; Di Carmine, G.; Zanotto, F.; Balbo, A. Inclusion of 5-mercapto-1-phenyl-tetrazole into $\beta$-cyclodextrin for entrapment in silane coatings: An improvement in bronze corrosion protection. Coatings 2019, 9, 508. [CrossRef]

29. Lahrour, S.; Benmoussat, A.; Bouras, B.; Mansri, A.; Tannouga, L.; Marzorati, S. Glycerin-grafted starch as corrosion inhibitor of $\mathrm{C}-\mathrm{Mn}$ steel in $1 \mathrm{M} \mathrm{HCl}$ solution. Appl. Sci. 2019, 9, 4684. [CrossRef]

30. Dagdag, O.; Hanbali, G.; Khalaf, B.; Jodeh, S.; El Harfi, A.; Deghles, A. Dual component polymeric epoxy-polyaminoamide based zinc phosphate anticorrosive formulation for 15CDV6 steel. Coatings 2019, 9, 463. [CrossRef]

31. Shinato, K.W.; Huang, F.; Xue, Y.; Wen, L.; Jin, Y. The protection role of cysteine for Cu-5Zn-5Al-1Sn alloy corrosion in 3.5 wt.\% NaCl solution. Appl. Sci. 2019, 9, 3896. [CrossRef] 
32. Lepojević, N.; Šćepan, I.; Glišić, B.; Jenko, M.; Godec, M.; Hočevar, S.; Rudolf, R. Characterisation of NiTi orthodontic archwires surface after the simulation of mechanical loading in CACO2-2 cell culture. Coatings 2019, 9, 440. [CrossRef]

33. Romasanta, L.J.; D’Alençon, L.; Kirchner, S.; Pradère, C.; Leng, J. Thin coatings of cerium oxide nanoparticles with anti-reflective properties. Appl. Sci. 2019, 9, 3886. [CrossRef]

34. Seo, Y.; Jung, J.-Y.; Chung, J.; Lee, S. Enhancement of corrosion resistance of aluminum 7075 surface through oil impregnation for subsea application. Appl. Sci. 2019, 9, 3762. [CrossRef]

35. Zhao, X.; Qi, Y.; Zhang, Z.; Li, K.; Li, Z. Electrochemical impedance spectroscopy investigation on the corrosive behaviour of waterborne silicate micaceous iron oxide coatings in seawater. Coatings 2019, 9, 415. [CrossRef]

36. D’Elia, M.F.; Magni, M.; Trasatti, S.P.M.; Schweizer, T.B.; Niederberger, M.; Caseri, W. Poly(phenylene methylene)-based coatings for corrosion protection: Replacement of additives by use of copolymers. Appl. Sci. 2019, 9, 3551. [CrossRef]

(C) 2020 by the authors. Licensee MDPI, Basel, Switzerland. This article is an open access article distributed under the terms and conditions of the Creative Commons Attribution (CC BY) license (http://creativecommons.org/licenses/by/4.0/). 